\title{
A RESISTÊNCIA DE ROSSELLINI, DE P. ADAMS SITNEY ${ }^{1}$
}

\section{Traduzido por Cid Vasconcelos*}

Menos de duas semanas após a invasão Aliada da Sicília e o bombardeio de Roma, o Gran Consiglio, essencialmente fascista, deu um voto de não confiança a Mussollini. Na manhã seguinte, 25 de julho de 1943, ele foi preso pelo recém-nomeado governo do General Badoglio e aprisionado na Ilha de Ponza, de onde os alemães o resgataram em setembro, apenas uns poucos dias após Badoglio chegar a um acordo para a Itália se tornar atuante com os aliados.

Esses eventos geraram uma coalizão de antifascistas de longa data, jovens patriotas que resistiram à ocupação da Itália, e figuras de todos os lados da arena política que havia chegado o tempo para uma nação transformada. Seu Comitê Nacional de Libertação (CNL) incluía brigadas de comunistas, socialistas (PSI), e o Partido da Ação (Partito d'Azione, movimento radical pela democracia liberal liderado por Ferruccio Parri, que posteriormente serviria como primeiro-ministro do pós-guerra, de junho a novembro de 1945) cooperando com liberais e católicos de extrema-direita no recém-formado Partido da Democracia Cristã (DC).

Muitos dos principais líderes dos partidos do CNL possuíam postos centrais no governo de Badoglio. Esses mesmos homens da Resistência permaneceram as figuras dominantes da vida política italiana, mesmo depois do governo da Frente Unida se estilhaçar ao final de 1945 sob a pressão tanto de Churchill quanto de Truman e a Democracia Cristã (juntamente com os partidos menores de centro e esquerda) tomarem firmemente o controle da nova república e o assegurá-lo por vinte anos. Palmiro Togliatti retornou de seu exílio em Moscou em março de 1944 para liderar o Partido Comunista (PCI). Pietro Nenni, o líder socialista, continuou a ser a principal oposição à esquerda. $\mathrm{O}$ bibliotecário do Vaticano Alcide De Gaspari liderou a DC e permaneceria primeiro ministro da queda de Parri até 1953. O exemplo paradigmático do legado continuado da Resistência e da longevidade política italiana seria o de Giulio Andreotti, que é primeiro ministro no momento que escrevo, e que ocupou essa posição em 1972-73 e 1978-79. Ele foi líder do movimento jovem democrata-cristão durante a Resistência e reapareceu nos anos 50 como o subsecretário do entretenimento que tentou suprimir a exportação de filmes neorrealistas temendo pela imagem internacional da Itália.

\footnotetext{
${ }^{1}$ Sitney ensina na Princeton University e é autor do clássico livro sobre o cinema vanguardista norteamericano Visionary Film: The American Avant Garde 1943-2000, publicado originalmente em 1974. O texto em questão se encontra em Vital Crises in Italian Cinema, sendo um extrato de capítulo do mesmo nome. Nova York: Oxford U Press, 2013, pp. 27-40.

* Doutor em Sociologia pela Universidade Federal do Ceará. Professor Adjunto da Universidade Federal de Pernambuco. E-mail: nickmovie@hotmail.com.
} 
O sucesso do CNL foi seguido por extremas e sanguinolentas represálias pelos alemães e fascistas de Salò. Talvez mais de um terço dos mais de cem mil combatentes da Resistência morreram no conflito. Outros milhares foram feridos e torturados. Mesmo após os alemães terem se retirado da Itália, muitos outros italianos morreram quando os guerrilheiros (partisans) tentaram acertar as contas com colaboradores e fascistas.

As maiores representações literárias da ocupação e da Resistência não surgiram antes de 1947 (Uomini e No [1945], de Elio Vittorini é a exceção): Il Sentiero dei Nidi di Ragno /A Trilha dos Ninhos de Aranha 2 , 1947), de Ítalo Calvino, La Casa in Collina (1947) e La Luna e i Falò /A Lua e as Fogueiras, ${ }^{3}$ 1950), de Cesare Pavese e La Agnese va a Morire (1949), de Renata Vigano.

Já em 1945 e 1946 ao menos sete longas-metragens ficcionais descreveram os movimentos de Resistência e Libertação. Por ordem de seus lançamentos, eles foram: Roma, Città Aperta (Roma: Cidade Aberta, Roberto Rossellini); Due Lettere Anonime (Mario Camerini), O’ Sole Mio (Giacomo Gentilomo), Um Giorno nella Vita (Um Dia Qualquer, Alessandro Blasetti), Paisà (Roberto Rossellini), Il Sole Sorge Ancora (O Sol Ainda se Levantará, Aldo Vergano), Pian dele Stelle (Giorgio Ferroni) e Vivere in Pace (Viver em Paz, Luigi Zampa). De todos somente os dois filmes de Rossellini conquistaram o status canônico na história do cinema italiano e internacional.

ROMA, CITTÀ APERTA

Roma, Città Aperta foi não somente o primeiro filme após a guerra a representar o passado recente italiano; foi, ao contrário de todos os filmes sobre a Resistência quando de seus lançamentos, igualmente um grande sucesso comercial. Quase todas as vertentes do espectro político o aclamaram. Em Il Popolo, órgão democrata-cristão, Carlo Trabucco escreveu:

Das duas partes, a primeira, na qual nenhum protagonista domina a ação, mas sim Roma, a cidade como um todo, que vive e treme, sofre e conspira, resiste e exalta a si mesma; essa primeira parte é verdadeiramente coral e é representativa de toda a população cujos méritos ocultos e anônimos foram bem registrados, com uma objetividade ausente de retórica. ${ }^{4}$

No diário comunista L'Unità, Umberto Barbaro louvou o filme, assim como Alberto Moravia o fez em La Nuova Europa. O primeiro reconheceu Eugen Dollmann na figura de Hartmann, o líder da SS e Pietro Caruso no chefe de polícia italiana não nomeado. Moravia, como Trabucco, identificou a figura de Don Morosini, o padre executado por ter ajudado a Resistência, por trás do ficcional Don Pietro. A revista Star ainda nomeou as duas mulheres mais velhas que aparecem na sequencia de abertura, moradoras da casa onde o comunista Manfredi se refugia, como Signora Riccieri e sua

\footnotetext{
${ }^{2}$ São Paulo: Cia das Letras, 2004.

${ }^{3}$ São Paulo: Berlendis \& Vertecchia, 2003.

${ }^{4}$ Nedo Ivaldi (org.), Convegno di Studi: La Resistenza nel Cinema Italiano del Dopoguerra (La Biennale di Venezia, XXXI Mostra Internazionale d'Arte Cinematografica, 1970), p. 9.
} 
empregada Nannina no número 51 da Piazza di Spagna, onde os líderes comunistas Alicata e Ingrao corrigiam as provas das impressões do L'Unita e Palmiro Togliatti permaneceu tão logo retornou à Roma. Barbaro ecoa a expressão "privado de retórica" de Trabucco em seu elogio a recriação da história recente efetuada pelo filme:

\begin{abstract}
A vida das habitações populares e seu sentimento unanime de ódio em relação aos nazifascistas, a casa abominável na Via Tasso [onde a Gestapo torturou aqueles suspeitos de auxiliar a Resistência] com todos seus subterrâneos imundos e sórdidos, palco de corrupção e traição, a miséria das ruas nas noites de toque de recolher e prisões, torturas, crimes, as figuras medonhas de Caruso e Dollman, tudo isso é lembrado com uma objetividade sem retórica e com um julgamento político implícito que é sensato e justo, de maneira que o filme indubitavelmente merece o louvor de todos os homens honestos. ${ }^{5}$
\end{abstract}

A ausência de retórica, louvada no filme, foi recorrentemente citada nas resenhas.

O conceito de "coralità", utilizado pioneiramente por Trabucco, posteriormente se tornaria um lugar comum na crítica do filme. ${ }^{6}$ Também foi utilizado por Alberto Vecchietti em sua resenha negativa publicada três dias após no jornal socialista Avantii. Numa das abordagens mais críticas ao filme, Vecchietti focou no sarcasmo posto pelo chefe da Gestapo Bergmann para com sua vítima, Manfredi, que seus aliados capitalistas no movimento antifascista logo se tornariam seus inimigos:

\begin{abstract}
Dessas declarações vem as mais sérias críticas a serem levantadas contra o filme de Rossellini. Um revolucionário, considerado em seu sentido pleno, possui toda a razão para aproveitar a oportunidade de livrar o país de suas autoridades de então, entregando-as em massa aos invasores. Uma resposta esclarecida assim o ditava. Uma resposta que honestamente teria esclarecido o novo espírito que, promovido pelo ethos do Comitê de Libertação, animava esses revolucionários no momento. No entanto, o protagonista do filme permanece silencioso. E juntamente com ele o filme silencia sobre muitos outros problemas, que de forma não menos vibrante são levantados. Assim, somos confrontados com um filme coral (o drama da cidade histórica mais uma vez invadida pelos bárbaros)? Ou um filme católico (tudo teria um sentido especial sobre a grande sombra e a grande luz que São Pedro lança sobre Roma)? Ou, por outro lado, o filme tenta particularmente expressar o espírito espontâneo do povo lutando sob a opressão (por isso é que as crianças e seu heroísmo fazem pensar)? Em outras palavras, não parece para nós que o filme saiba como desenvolver seu tema $[\ldots]^{7}$
\end{abstract}

A resposta americana mais interessante a Roma: Cidade Aberta foi refratada através da perspectiva do partidarismo político. O romancista James T. Farrell, escrevendo regularmente como fazia na publicação mensal trotskista The New International, demonstrava que Manfredi era um "funcionário stalinista" erigido ao status de herói:

Este é precisamente o tipo de mito que os stalinistas desejam que as pessoas engulam. Além do que, Manfredi é estabelecido como o herói principal de Cidade Aberta. Ainda que seja verdade, no entanto, que o filme incorpore um conteúdo de colaboracionismo entre o Partido Comunista e a Igreja, esse conteúdo possui um componente especial assim como geral, e é

\footnotetext{
${ }^{5} \mathrm{Ib} ., \mathrm{p} 10$.

${ }^{6}$ Ver Peter Brunette, Roberto Rossellini (Nova York: Oxford University Press), pp. 28, 50.

${ }^{7}$ Ivaldi, La Ressintenza, pp. 10-11.
} 
sobre essa característica especial que essa análise se detém. Omissões que estabelecem que o mito stalinista possa dar crédito, por sua vez, a mitos católicos. A Igreja, como representada por Don Pietro é apresentada somente sob uma luz benevolente. ${ }^{8}$

Ao enfatizar o heroísmo pessoal de Manfredi e deixar suas ideias na obscuridade,

[a] arte é dada uma função prática. Essa função não é cumprida por uma simples e obtusa função didática, mas antes com o auxílio de uma tendenciosa caracterização, organização do enredo e uma tendenciosidade nos detalhes. Essa tendenciosidade serve, igualmente, ao propósito de distorcer e dissimular a política de um filme político. ${ }^{9}$

Hoje, quarenta e cinco anos após a resenha de Farrell, Rossellini parece ter sido tudo menos que um calculado propagandista do PCI. De fato, ele foi o representante da DC junto aos trabalhadores de cinema no Comitê Nacional de Libertação. Citei a forte incompreensão de Farrell do filme em parte por conta de se focar insistentemente em sua mensagem política, mas ainda mais por conta de ter suscitado uma resposta altamente sofisticada do historiador de arte Meyer Schapiro, que de muitas formas prefigura minha análise do filme e, até certo ponto, o método crítico desse livro como um todo.

Citarei a resposta de Schapiro em sua extensão:

A colaboração com a Igreja constitui, em minha opinião, o tema básico do filme. Ela é realizada em muitos detalhes e assume mesmo o padrão de uma familiar lenda cristã. $\mathrm{Na}$ conclusão, sempre vital para o efeito de filme ou de uma peça, os dois mártires, Pietro e Manfredi, evocam os martírios de Pedro e Paulo em Roma. Como Paulo, Manfredi é o apóstolo vibrante e descompromissado; como Paulo, ele inicia como um perseguidor da Igreja, e como Paulo morre sob outro nome, mais cristão que o seu original. O padre, Pietro, emitiu para ele um passaporte falsificado como Giovanni Episcopo [Bispo], e é sobre esse sugestivo nome (o mesmo de um personagem de d'Annunzio) que a Gestapo registra sua morte. Posso me permitir nesse contexto levar a matriz mítica ainda mais longe e observar que assim como São Pedro foi crucificado de cabeça para baixo, o padre Pietro é baleado pelas costas $[\ldots]$.

[...] os sacramentos surgem como instrumentos flexíveis à disposição dos quereres humanos, mas que ritos mágicos administrados sob condições exclusivas. O padre escuta a confissão de Pina enquanto a acompanha pela rua, quando se encontra a missão da Resistência, enquanto um ser humano em relação a outro. $\mathrm{O}$ rito da extrema-unção é encenado como um estratagema para enganar a Gestapo e salvar Romoletto, cuja bomba pode ser descoberta pela busca do inimigo à casa [...]. Ao público é dado o sentimento de que a Igreja é tolerante, humana, calorosa, adaptável, superior ao dogma e ao rito [...].

[...] A religiosa Pina, a verdadeira heroína, não somente é uma crente, como se conforma aos ensinamentos da Igreja sobre as condutas e formas de se vestir. Se ela vive em pecado, isso se dá por conta das condições incertas da guerra; ela está prestes a se casar na igreja. Em oposição a ela se encontra a amante do comunista Manfredi e que, em última instância, lhe trai através da espiã alemã, Ingrid. A última, figura sinistra, assemelha em suas características e ações as mulheres cruéis de Beardsley e a literatura dos anos 1890, a vamp ou Salomé do período. Ela é lésbica e odeia os homens. Suas questões políticas emergem de uma deformidade psicológica. [...] De forma similar, o chefe da Gestapo é um homossexual

\footnotetext{
${ }^{8}$ James T. Farrell, Literature and Morality (Nova York: Vanguard Press, 1946). Reimpresso, com extensa revisão, incluindo a passagem citada, de New International (agosto de 1946).

${ }^{9}$ New International (agosto de 1946), p. 187.
} 
estimulado por uma fria vaidade e sadismo. [...] A polaridade: alemães-italianos, é forte, mais decisiva que as diferenças entre os italianos.

[...] Existem muitos que sinceramente acreditam que a unidade da Resistência poderia ser mantida após a guerra, ainda que fosse pela liderança do Partido Comunista. No filme, o destaque a Pina e ao padre, em termos humanos, dramáticos e artísticos é tal que supus a princípio que o todo fosse obra de homens próximos do povo e do padre, de alguma maneira no sentido de Silone, que do Stalinismo, apesar de certos toques sugerirem uma mão stalinista. ${ }^{10}$

Schapiro reconhece, como nenhum crítico italiano de sua época parece ter feito, o grau através do qual o cinema italiano, ao menos enquanto exemplificado por Roma: Cidade Aberta, reflete e reformula a tradição iconográfica da arte renascentista. Talvez tais associações fossem tão óbvias que os críticos nativos não acharam digno de mencioná-las, ou talvez estivessem tão profunda e universalmente interiorizadas que não as tenham percebido conscientemente. Ao longo desse livro pretendo analisar as dimensões iconográficas de alguns dos maiores filmes italianos, fundindo essa perspectiva crítica à discussão de pontos tópicos e históricos, tais como os apontados pelos críticos italianos.

Uma discussão sobre uma alusão localizada pode nos levar a esclarecer as nuances políticas, cuja ausência das quais leva Farrell ao erro, assim como em alguma medida Schapiro. Por exemplo, antes de Roma: Cidade Aberta ter sido concebido, quer dizer, tão cedo quanto no verão de 1944, o realizador Giuseppe De Santis preparava o roteiro para um filme a ser intitulado G.A.P. (acrônimo de Gruppi di Azione Patriottica, o menor dos grupos urbanos que compunham o CNL) com a colaboração de uma série de guerrilheiros comunistas, incluindo Antonello Trombadori, Franco Calamandrei e Gianni Puccini. Um dos episódios descreveria a morte de Maria Teresa Gullace, uma mulher grávida que tinha cinco filhos, morta por um soldado alemão em frente as barracas onde seu marido estava detido e esperava ser deportado para um campo de trabalhos forçados; diante de uma multidão de mulheres, ela se aproximou de uma das janelas da tenda e jogou ao marido um pacote de comida. ${ }^{11}$ Por isso, ela foi morta. O GAP fez uma represália imediata: dois guardas fascistas foram alvejados nas barracas e três caminhões foram explodidos. ${ }^{12}$ Além do que, de acordo com Maria Michi, que interpreta Marina Mari (a amante de Manfredi que o trai, em última instância, por drogas), o roteirista Sergio Amidei foi responsável pela narrativa do filme, adaptando das experiências contadas para ele pelos guerrilheiros comunistas, incluindo Togliatti e Celeste Negarville. ${ }^{13}$

$\mathrm{Na}$ verdade, Roma: Cidade Aberta teve sua gênese em outra direção política: Rossellini havia sido incumbido de realizar um documentário sobre Don Giuseppe Morosini, um veterano capelão militar que foi a Roma em julho de 1943. Trabalhando para o bando de guerrilheiros de "Mosconi", ele roubou planos sobre as estratégias alemãs em Monte Cassino e os contrabandeou para os aliados. Depois de ter sido denunciado por

\footnotetext{
${ }^{10}$ Meyer Schapiro, “A Note on the 'Open City”, New International (dez. 1946), pp. 312-3.

${ }^{11}$ Enzo Piscitelli, Storia Della Resistenza Romana (Bari: Laterza, 1965), pp. 285-6.

${ }^{12}$ Gianni Rondolino, Roberto Rossellini (Turim: UTET, 1989), pp. 69-75; Piscitelli, Storia Della Resisnteza Romana, pp. 286-7.

${ }^{13}$ Rondolino, Rossellini, p. 76.
} 
recompensa e preso, trabalhou com prisioneiros políticos e judeus na prisão de Regina Coeli até sua execução em Forte Bravella nas cercanias de Roma, em 4 de março de 1944. Rossellini incorporou um detalhe da execução no filme: seja por que não havia balas o suficiente ou pelo esquadrão ter deliberadamente errado o alvo, ele não foi alvejado até um oficial fascista atirar duas balas em suas cabeças. ${ }^{14}$

Quando De Santis abandonou o GAP ele foi trabalhar com Mario Serandrei no documentário Giorni di Gloria (Dias de Glória), que foi lançado um mês após Roma: Cidade Aberta, no outono de 1945. Essencialmente Rossellini assumiu aspectos de sua recriação ficcional da Resistência, enquanto De Santis e os colaboradores comunistas concentraram seus esforços num filme factual que recordava o julgamento e as execuções de Pietro Caruso e Piero Koch, o líder da câmera de torturas da Pensione Jaccarino, e recriaram através da montagem a ação mais dramática efetuada pela GAP em Roma - a explosão de uma bomba na Via Rasella que matou 33 alemães. Em retaliação a SS executou 335 prisioneiros, metade deles judeus e selou os corpos num subterrâneo da Via Ardeatine. Luchino Visconti, que se encontrava entre as vítimas de Koch, tanto testemunhou contra ele como dirigiu a filmagem do julgamento. O diretor Marcello Pagliero construiu a sequência do massacre das caves da Via Ardeatine. O mesmo Pagliero interpretou o comunista Manfredi no filme de Rossellini.

Rossellini combinou o que ele "testemunhara" do projeto de De Santis com a comissão Don Morosini. Assim como reteve o suficiente da história de Gullace na personagem de Pina para manter a alusão específica pertinente, baseando a figura de Manfredi na do conhecido herói da Resistência. Roy Armes recorda que o modelo foi Celeste Negarville. ${ }^{15}$ Negarville foi um comunista de Turim, preso em Bolonha em 1927 e condenado a 12 anos de prisão por crimes políticos. Em 1934, no entanto, ele foi solto numa anistia que celebrava os dez anos do governo fascista. Ele fugiu para a França e comandou o escritório parisiense do PCI por um ano antes de partir para Moscou e servir no presídio da Internacional de Jovens Comunistas. Entre 1938 e 1943 e se estabeleceu na França. Voltou para a Itália em janeiro de 1943 e foi eleito como representante do PCI para o comando militar do CLN. Na época que Rossellini realizou Roma: Cidade Aberta, Negarville era editor de $L$ 'Unità e subsecretário de estado do gabinete de Parri. ${ }^{16}$

Rossellini e Amidei ficaram próximos demais da história de Negarville para a tornarem reconhecível, porém deram uma torção melodramática na mesma. Quando Bergmann e a figura não nomeada de Caruso descobrem a biografia de Manfredi, pseudônimo para Luigi Ferrara (o nome em código de Negarville na clandestinidade era Gino Ferri), datam seu nascimento e prisão em Bolonha um ano após, respectivamente, aos ocorridos com Negarville; e, ainda mais significativo, o perdão se transforma numa fuga e no filme ele é capturado e torturado até a morte pelos capangas de Bergmann.

Roma: Cidade Aberta foi uma produção de baixo orçamento, expressão oportuna de um momento histórico no qual o acabamento dos estúdios não poderia ter sido adquirido ainda que Rossellini e seus colaboradores não estivessem lutando para apenas

\footnotetext{
${ }^{14}$ Enciclopedia dell'Antifascismo e della Resistenza (Milão: La PIetra, 1976), 3: 826. Ver também Brunette, Rossellini, p. 364. Nota 5.

${ }^{15}$ Roy Armes. Patterns of Realism (South Brunswick, NJ/Nova York: Barnes, 1971), p. 68.

${ }^{16}$ Franco Andreucci e Tomasso Detti, Movimento Operaio Italiano: Dizionario Biografico, 1853-1943 (Roma: Editora Reuniti, 1977), 3: 656-658.
} 
completar o filme. Além do que, é um lugar comum da crítica que esses meios precários emprestaram ao filme um visual autêntico. Sem querer polemizar com essas verdades, pretendo elaborar um argumento de como ousados lances de diretor aprimoraram o poder desse filme sincero e mesmo simples. ${ }^{17} \mathrm{O}$ primeiro foi o som. $\mathrm{O}$ filme inteiro teve de ser sincronizado após a filmagem ter sido completada. Isso permitiu a Rossellini desenvolver uma abordagem "realística" dos diálogos: os italianos falam sua língua nativa, enquanto os alemães, quando falam entre si, a deles. Contudo, as consequências dessa escolha foram tanto estruturais quanto políticas. Para compreendê-las enquanto tal, precisamos observar a singularidade da representação dos alemães nesse filme e compreender a motivação política por trás dessa singularidade.

O filme efetivamente apela por uma unidade italiana numa época que muitos sentiam a necessidade de punir todos os que haviam cooperado com os fascistas. Os alemães de Rossellini monopolizam a vilania. O sargento italiano fascista olha para o outro lado quando uma mulher faminta assalta uma padaria; ${ }^{18}$ posteriormente, ele auxilia o Padre Don Pietro a encobrir as crianças do grupo da Resistência quando os alemães cercam o apartamento onde Pina e Francesco ocultavam Manfredi. Um tipo cômico de policial bem intencionado mas débil, o sargento representa a polícia fascista como objeto de divertimento mais que de vingança. O comissário de polícia, o colaborador mais próximo da SS alemã, não possui características carismáticas. Entretanto, o gordo e calvo burocrata se torna uma figura de pathos quando silenciosamente tolera o desprezo de Bergmann pelos italianos. O observamos somente na companhia de Bergmann, onde ele desempenha a função de contraste para a malícia de seu duplo, conduzindo fora da tela a pesquisa que revela a real identidade de Manfredi.

Ao concentrar todo o mal nos alemães, Rossellini descobre um bode expiatório seguramente distante que não desempenhará qualquer papel na situação política de 1945 . Um sinal de seu realismo é a incorporação da língua alemã. Isso os distancia do observador italiano, que tem que ler as legendas para saber o que estão dizendo, como se fosse "por trás de suas costas".

Para provocar um distanciamento ainda maior da Gestapo, ele retrata as duas figuras mais notórias como estereotipados homossexuais. Rossellini escalou Harry Fest, um dançarino de balé, como Bergmann, dirigindo seus gestos para sugerir uma "diva do teatro". Os gritos e o sangue de suas vítimas torturadas o ofendem esteticamente; à repetição monótona de tais torturas, ele afirma ser "entediante". Ainda que nunca o vejamos expressando desejo sexual, sua elegante e carniceira agente, Ingrid, evoca uma paródia de Marlene Dietrich num papel explicitamente lésbico. Ela acaricia repetidamente Marina, a namorada de Manfredi, a quem seduz com drogas e peles. É sugerido que ela tenha sido a fonte original do vício agora incurável de Marina.

Um terceiro alemão, o oficial aristocrata e heterossexual, Hartmann, reconhece em meio a drinques, o fracasso da ideia de uma raça superior. Ainda que ele não possa executar calmamente Don Pietro na cena final do filme. Aqui o vemos fora do trabalho,

\footnotetext{
${ }^{17}$ Ver Brunette, Rossellini, p.44, para um sumário da crítica de Amidei da "absoluta convencionalidade" dos "elementos de narrativa popular" do filme.

${ }^{18}$ Giorgio Amendola, Lettere a Milano: Ricordi e Documenti, 1939-1945 (Roma: Editora Riuniti, 1974), p. 185. Amendola lembra que o esforço guerrilheiro na Roma ocupada frequentemente tomou a forma de convulsões espontâneas a partir de motivos pequenos. Ele menciona a cena do filme de Rossellini como ilustrativa de seu argumento.
} 
na luz mais severa através da qual o realizador implicitamente dotou como teatro da realidade. Ainda que um italiano tenha terminado a execução do Morosini real e um italiano o tenha traído a Gestapo por 70 mil liras, a representação ficcional recria esses eventos para reforçar a germanização do mal no filme.

A maior parte do tempo, encontramos os alemães em interiores, nos locais de interrogatórios, onde a música de piano não pode encobrir os gritos dos prisioneiros. E é uma façanha notável do filme de Rossellini disfarçar esse drama de moralidade melodramática e alegoria política como realismo. Uma das condições de nossa aceitação do comportamento teatral dos alemães é sua diferença dos italianos.

Planos e sons sugestivos de instrumentos e maçaricos efetivamente condensam as cenas de tortura. Os gritos que podem ser escutados no escritório de Bergmann através das portas abertas, sempre que seus assessores entram ou saem acentuam a crueldade de seus maneirismos hiper-estilizados e sugerem, por conta de ser deixado demasiado para nossa imaginação, um círculo de terror ao redor do limitado teatro de postura nazista. Portanto, as limitações econômicas de um palco de som improvisado (onde a sede nazista foi construída) e os problemas com mixagem de som, forçaram Rossellini a uma situação onde sua imaginação triunfou: a pontuação compassada dos sons da tortura nos distrai dos banais e cinematograficamente convencionais diálogos dos aposentos e, mais profundamente, criam o contexto no qual as cenas alemãs grandemente encenadas podem ser absorvidas numa retórica do realismo.

O mito que o cinema italiano neorrealista surgiu com a realização de Roma: Cidade Aberta testemunha, em última instância, o poder senão do caráter único do filme de Roberto Rossellini, já que em termos estilísticos e políticos ele continua a obra anterior de Rossellini e outros realizadores, como Brunette elabora em sua análise sobre o realizador e James Hay argumenta, de forma mais ampla, em seu Popular Film Culture in Fascist Italy. Sua produção se beneficiou de uma quase causalidade temporal: como o primeiro filme sério da Itália Libertada, atraiu atenção internacional como um drama moral que purga o Fascismo. A aparente ambivalência de Rossellini sobre as opções políticas de renovação do Estado italiano pode, de fato, ter fortalecido o filme, afastandoo da esfera das ideologias conflitantes do movimento de Libertação italiano. Uma ambivalência semelhante ocorre no domínio da política eleitoral tomando a forma de um desejo por um cenário político completamente novo, manifestado ele próprio no sucesso do Partido da Ação; sem falar que Roma: Cidade Aberta não reflete diretamente a plataforma do Partido da Ação, mas meramente que tanto o filme quanto o partido se encontravam prenhes com uma energia de uma visão otimista de um consenso de CentroEsquerda que iria dirimir de forma clara as ameaças tanto de revolução quanto de um retorno a uma forma modificada de Fascismo.

Naturalmente, a criatividade auditiva não funcionou exclusivamente em retratar os alemães. $\mathrm{O}$ bando de crianças que imita as ações da Resistência fala o dialeto romano. A canção de resistência que assobiam ao final do filme, ao testemunhar a execução de Don Pietro, em um campo nos arredores da cidade, contrabalança a canção alemã ouvida no momento imediato de abertura do filme, quando os soldados marcham ao amanhecer pela Piazza di Spagna procurando por Manfredi. Sua presença é introduzida por outra sonoridade: o noticiário ilegal da $\mathrm{BBC}$ no rádio, no apartamento onde ele se refugia. A riqueza sonora do filme é ressaltada pela efetiva, ainda que convencional, trilha sonora de Renzo Rossellini, irmão do diretor. 
Angela Dalla Vacche, que argumenta em The Body and the Mirror que uma dialética entre a ópera e a commedia dell'arte animam a imagem do corpo no cinema italiano mais relevante, identifica a obra de Rossellini com a última:

\begin{abstract}
Em contraposição aos heróis de mármore do cinema fascista, o corpo no Neo-Realismo de Rossellini, é o organismo humano habitado pela antítese da pura biologia, a alma, como se a espiritualidade cristã se desenvolvesse próxima a uma abordagem pagã na terra. Ao representar o impacto da história oficial na vida cotidiana e pessoas anônimas, o neo-realismo adotou a escala microscópica da commedia dell'arte e voltou às costas ao cenário monumental da ópera. ${ }^{19}$
\end{abstract}

A dialética entre ópera e commedia dell 'arte na realidade opera dentro do filme em contraste aos fatos heroicos dos protagonistas que Dalla Vacche chama "vida cotidiana e pessoas anônimas". A herança da commedia dell'arte é exemplificada pela segunda estratégia brilhante que Rossellini utiliza: representar os italianos como figuras cômicas. Rossellini evita a caricatura latente da oposição entre alemães malévolos e italianos benignos, ao desviar o eixo da polaridade para alemães sem senso de humor e, em última instância, ineficientes contra italianos divertidos e bem-humorados cujo heroísmo trapalhão é bem-sucedido.

As velhas senhoras que abrigaram Manfredi, em pânico de um lado para outro quando os nazistas chegam, o avô acamado na casa de Pina, obcecado com a ideia de comer bolo de noiva, o sacristão gentilmente hipócrita que recebe pão roubado e o sargento já mencionado proporcionam um coro cômico. Próximo do centro emocional do filme se encontra a gangue infantil dos rapazes de ideais de Resistência sob a liderança do deficiente Romoletto. Esses rapazes podem explodir um caminhão alemão, mas se encontram temerosos de enfrentar seus parentes ao chegarem tarde em casa. Por fim, no próprio cerne do filme, existe dois esplêndidos comediantes, o clown Aldo Fabrizi que interpreta Don Pietro e Anna Magnani, atriz de cinema mais conhecida como intérprete do teatro de variedades, cuja Pina é uma das grandes interpretações do moderno cinema italiano. Don Pietro, padre efeminado e um personagem cômico de apoio, apresenta irrestrita bravura quando necessário. Porém, primeiro o observamos desajeitadamente jogando futebol com seus estudantes, levando uma bolada na cabeça acidentalmente. Ele é uma mescla de gordo desajeitado e sexualmente ingênuo: quando tem que efetuar uma transferência de dinheiro para a Resistência, vai a uma loja de bugigangas. Enquanto espera, observa uma estátua de São Roque em um mostruário que aparenta olhar o busto de uma vênus despida. Don Pietro vira ao inverso a estátua de São Roque, logo ao perceber que ele havia exposto o traseiro da deusa ao santo de gesso.

Sua atuação cômica por excelência ocorre quando ele corre ao edifício onde se encontra o apartamento de Pina, sob o pretexto de executar uma extrema-unção, para esconder as armas de Romoletto. Primeiro ele faz um salvamento chaplinesco de uma granada que retira da mesa, escondendo um rifle com sua batina. O ritmo é primoroso e pura comédia pastelão, incluindo a captura, com olhos esbugalhados, da bomba. Então, coroando tudo isso, ele tem que acertar o avô com uma panela pois o velho senhor, sem

\footnotetext{
${ }^{19}$ Angela Della Vacche, The Body in the Mirror: Shapes of History in Italian Cinema (Princeton: Princeton U Press, 1992), pp. 180-1.
} 
compreender a situação, não se presta a fazer papel de morto. Como toque final, ele o reanima, de forma cômica, encharcando-o com a água benta de seu aspersório.

Pina é uma prática, briguenta e espalhafatosa romana que instantaneamente se transforma em uma figura maternal e dedicada quando um membro da resistência ou padre se aproxima. Quase tão rapidamente ela pode desdenhar de um fascista ou irromper em tapas quando o filho chega tarde em casa. Mais que projetar a instabilidade do personagem dessa maneira, sugere-se dela ser um poço de autoconfiança com tal riqueza pelo amor e pela justiça que o espectador se identifica com seus gestos e os reconhece como apropriados. Mesmo um soldado alemão, um troglodita teutônico próximo de uma representação de desenho animado que a segura pelas mãos quando o apartamento é esvaziado para ser revistado, sujeita-se a sua autoridade moral.

O par romântico do filme, Manfredi e Marina, a bela amiga de sua fútil irmã, não provém do núcleo cômico do filme, mas interpretam papéis menores. Pina e Don Pietro dominam o filme. O noivo de Pina, Francesco, cujo nome reflete sua brandura, não é igualmente um cômico, mas se encontra completamente inserido no universo grandemente espirituoso da família de Pina, onde funciona como pacificador e figura paterna para um filho de pai falecido.

A falta de humor, perversidade e mesmo caráter lúgubre dos alemães - o chefe dos torturadores se assemelha a uma versão hollywoodiana do monstro de Frankenstein ressaltam o aspecto cômico dos romanos. De forma propagandística, a visão cômica ao mesmo tempo que enfatiza o terreno humanista de uma tendência ao erro e solicita nossa tolerância a ele, esvazia a maldade do Fascismo nativo, como se a bondade de uma Pina ou de um Don Pietro pudesse redimir a fraqueza dos cômicos fascistas. A diferença em tom entre a representação dos italianos e dos alemães previne que a boa vontade induzida pela comicidade se estenda a todas as figuras do filme e, portanto, confunda e dilua a mensagem política.

Ainda que Rossellini faça uso de figuras e esquetes cômicos, seu filme não é de forma alguma uma comédia. Isso pode ser percebido mais claramente em seu uso da ironia, que é consistentemente trágica. No próprio clímax do momento mais cômico do filme - o sábio despiste do padre do assalto da batida ao apartamento - Pina é assassinada. Sua morte é triplamente irônica. Em primeiro lugar, nenhum dos sofrimentos ocorridos em Roma: Cidade Aberta precisava ter ocorrido. O título se refere a um local, Roma, e uma época, o período da ocupação alemã da cidade, após o General Kesselring entrar em acordo com o Vaticano que a cidade não seria um campo de batalha; a cidade aberta logo seria abandonada pelos alemães com a chegada dos americanos. Todos os esforços de Bergmann eram em nome de uma causa perdida, como ele admite no filme. Em segundo lugar, a cópia de Resistência da gangue de Romoletto chama a atenção da Gestapo para o edifício onde se encontra refugiado Manfredi. Seu ataque a bomba a um caminhão não desempenha nenhuma função estratégica; foi um ato indisciplinado, sem a sanção da cúpula do movimento organizado da Resistência. E, por fim, e mais importante, não houvesse Pina corrido imprudentemente atrás de Francesco, quando ele é levado em um caminhão, não teria morrido e teria sido capaz de celebrar seu casamento com ele esse dia; a Resistência organizada foi bem-sucedida em emboscar os caminhões de prisioneiros na cena seguinte, libertando todos que se encontravam cativos. Naturalmente, ela não podia saber disso. Ao contrário, ela corre atrás do caminhão que parte, apenas para ser atingida no meio da rua diante dos olhos de seus vizinhos, do padre e de seu filho. 
A cena é a montagem mais dramática do filme, intercalando planos do caminhão em movimento, da mulher correndo e das testemunhas. Guardadas as devidas dimensões, é a Escadaria de Odessa de Roma: Cidade Aberta.

Mesmo esta cena melodramática foi inspirada por um incidente cômico ocorrido durante as filmagens, de acordo com o roteirista Sergio Amidei. Após uma noite de filmagem, Magnani discutiu com um amigo. Ele foi até um caminhão da produção, que partiu com ela correndo e berrando imprecações obscenas. A explosão temperamental de Magnani, material para comédia, tornou-se algo bastante diferente quando traduzida no filme.

Nada nos prepara para a morte súbita de Pina. Após ela, a comédia finda. O último ato do filme descreve as mortes de Manfredi e Don Pietro nas mãos da Gestapo. Uma ironia a mais poupa Francesco novamente. Marcello, o filho de Pina, o detém por um momento para lhe dar um cachecol como lembrança de sua mãe. Nesse momento, a Gestapo captura Don Pietro e Manfredi. Francesco estaria com eles, caso essa intervenção não houvesse ocorrido. O filme encoraja, dessa maneira, um público católico observar essa cena como uma obra quase milagrosa de uma "mãe no céu", tanto salvando seu noivo quanto proporcionando um padrasto para seu filho.

O perspicaz artigo de Meyer Schapiro aponta para as funções dos sacramentos no filme. Ele poderia ter levado esse argumento ainda mais longe: na transformação sutil do ritual os sete sacramentos não apenas se tornam "instrumentos flexíveis à disposição dos desejos humanos", mas assumem igualmente um novo sentido político. Aqui o casamento de Francesco e Pina é a união do Comunismo e do Catolicismo, estimulado pelas provações da guerra, mas também interrompido por sua violência. $O$ filme aponta, de forma otimista, para um período de renovação nacional e justiça social (sem represálias contra aqueles que foram seduzidos pelo Fascismo) que é melhor resumido pelo discurso de Francesco a Pina com o qual ele a consola após um entrevero que ela havia tido com sua irmã: "Não podemos ter medo agora ou no futuro. Porque estamos certos [...]. Talvez o caminho seja difícil, possa levar um longo tempo, mas veremos um mundo melhor! $\mathrm{E}$ nossas crianças irão vê-lo!". O filme termina com a imagem do grupo de meninos que havia imitado a Resistência voltando ao centro de Roma do local na periferia onde Don Pietro foi alvejado. A cidade a qual retornam é dominada pela imagem da cúpula de São Pedro.

Todos os sete sacramentos são submetidos a uma transformação em seus opostos políticos. Pina se encontra grávida de uma relação que antecede o casamento com Francesco; seu feto morre com ela, sem ser batizado. Da mesma forma, o enredo circula ao redor do "batismo" de um jornal, L'Unità, órgão clandestino da Resistência comunista; Marcello conta a Don Pietro que ele faltou várias vezes as aulas porque "do jeito que as coisas vão", fazer catecismo é uma perda de tempo; ele se prepara, ao contrário para sua "comunhão" imitando os que lutam na gangue de Romoletto; Pina tenta se confessar antes do casamento, mas obrigações políticas não permitem que Don Pietro a escute; posteriormente, ele deixará Manfredi morrer reassegurando que "você não falará" quando a Gestapo tenta, através da tortura, arrancar uma confissão sua; Pina e Francesco não tem seu casamento na igreja, mas a entrega do cachecol reassegura a continuação da "família" dela. Por fim, mesmo as Ordens Sagradas possuem seu lugar no filme: Bergmann não quer tornar Manfredi um mártir, então ordena que ele seja enterrado sob seu pseudônimo, Giovanni Episcopo. Esse nome, como muitos na Resistência, era uma 
alusão literária, nesse caso a criação ficcional de D’Annunzio. Mas epíscopo é a palavra italiana para "bispo"; portanto, no final, o herói ateu é ordenado e elevado. Pouco antes de sua morte a câmera enquadra seu torso ensanguentado com os braços estendidos para além do enquadramento, sugerindo a imagem do Cristo crucificado.

Don Pietro dá uma falsa extrema-unção ao avô, após nocauteá-lo; pouco depois, ele efetua o rito verdadeiro para Pina. De fato, observamos a missa da comunhão em seu funeral, mas a celebração eucarística se encontra dispersa ao longo do filme - quando ela oferece comida a Manfredi, quando esse chega, na confusão popular sobre o pão e no abate das ovelhas no mercado negro para um restaurante onde os membros da Resistência se reúnem em segurança.

Na crítica contemporânea de Roma: Cidade Aberta, a acusação de retórica era uma séria condenação estética. Já citei duas resenhas positivas ao filme, de tendências políticas opostas, exaltando o filme por sua ausência de retórica. No jornal independente Il Tempo, Fabrizio Zarazan elogiou a primeira parte do filme em detrimento do todo: "Rossellini caiu numa retórica de Grand Guignol que nem proporciona prazer nem segue as leis puras e fixas da transformação poética". ${ }^{20}$ Mesmo no interior do filme a questão da retórica surge. Suas implicações revelam o mais sutil dos ardis de Rossellini com relação às complexidades da política presente. Bergmann fala a Manfredi: "Vocês italianos, sejam a qual partido pertencem são todos viciados em retórica. Porém, eu estou confiante que você verá as coisas do meu modo antes do amanhecer". Ele quer dizer, naturalmente, que a consideração de Manfredi que ele tem esperança de que se encontre ao nível de outros membros da Resistência que foram torturados sem confessar é sem fundamento, e que após uma noite de torturas, ele confessará. O filme prova que Bergmann se encontrava errado em sua convicção de que podia dobrar Manfredi, mas isso não refuta a consideração do vício nacional à retórica. Através do personagem de Pina, Rossellini admite o emocionalismo do caráter italiano. Quando ela e Francesco gritam um para o outro após sua detenção, eles são engolfados por um momento operístico que custará a vida de Pina. O filme sugere através desta cena que o emocionalismo que até agora tinha sido visto como uma característica redentora nacional é também um perigo para a construção de uma sociedade no pós-guerra na Itália. Quando recordamos que muitos observadores, em 1945, antecipavam uma revolução armada na Itália, a advertência contra as trágicas consequências da ação melodramática é pertinente. O filme de Rossellini clama por um consenso popular mais amplo, englobando tanto a esquerda quanto a Igreja, baseado numa valorização inquestionável da família nuclear, heterossexualidade e o bem-estar dos italianos. Ao mesclar melodramaticamente versões das histórias de Gullace, Negarville e dos grupos de crianças da Resistência com a biografia de Don Morosini, Rossellini enfatizava a centralidade da misericórdia católica para esse consenso imaginário.

Recebido em 09/04/2016. Aprovado em 23/06/2016.

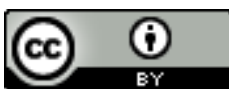

Este texto está licenciado com uma Licença Creative Commons Atribuição 4.0 Internacional.

${ }^{20}$ Ivaldi, La Resistenza, p. 11. 